\title{
Effects of Climate Change and Land Use on Water Resources in the Upper Colorado Riyer Basin
}

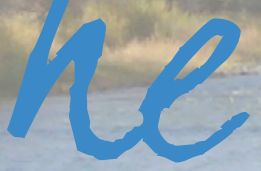

The health of the Colorado River watershed (fig. 1) is critical to the socioeconomic and ecosystem well-being of the Southwestern United States. Water in springs, streams, and rivers supports a range of aquatic and riparian ecosystems that contain many endangered species. Terrestrial habitats support a wide array of plants and wildlife. In addition, this region is enjoyed by millions of people annually for its recreational and esthetic opportunities. The Colorado River provides water for about 25 million people and is used to irrigate 2.5 million acres of farmland. However, competition for this water is expected to increase as human populations dependent on this water are projected to increase to 38 million by 2020 (Pulwarty and others, 2005).

Climate change is expected to further exacerbate water issues in this region. Drought in the Southwest during 2000-04, caused by both reduced precipitation and a series of the hottest years on record, resulted in streamflows lower than during the 1930s Dust Bowl or the 1950s drought (Andreadis and Lettenmaier, 2006). Increased temperatures alone are a major factor in reducing surface-water flows in this region. For instance, precipitation received during the winter of 2005 was at the 100-year average. However, low soil moisture and high January-July temperatures resulted in flows that were only 75 percent of average (National Research Council, 2007). Climate models predict future warmer temperatures and reduced precipitation in the Upper Colorado River Basin (UCRB), which would reduce water available to humans and ecosystems.

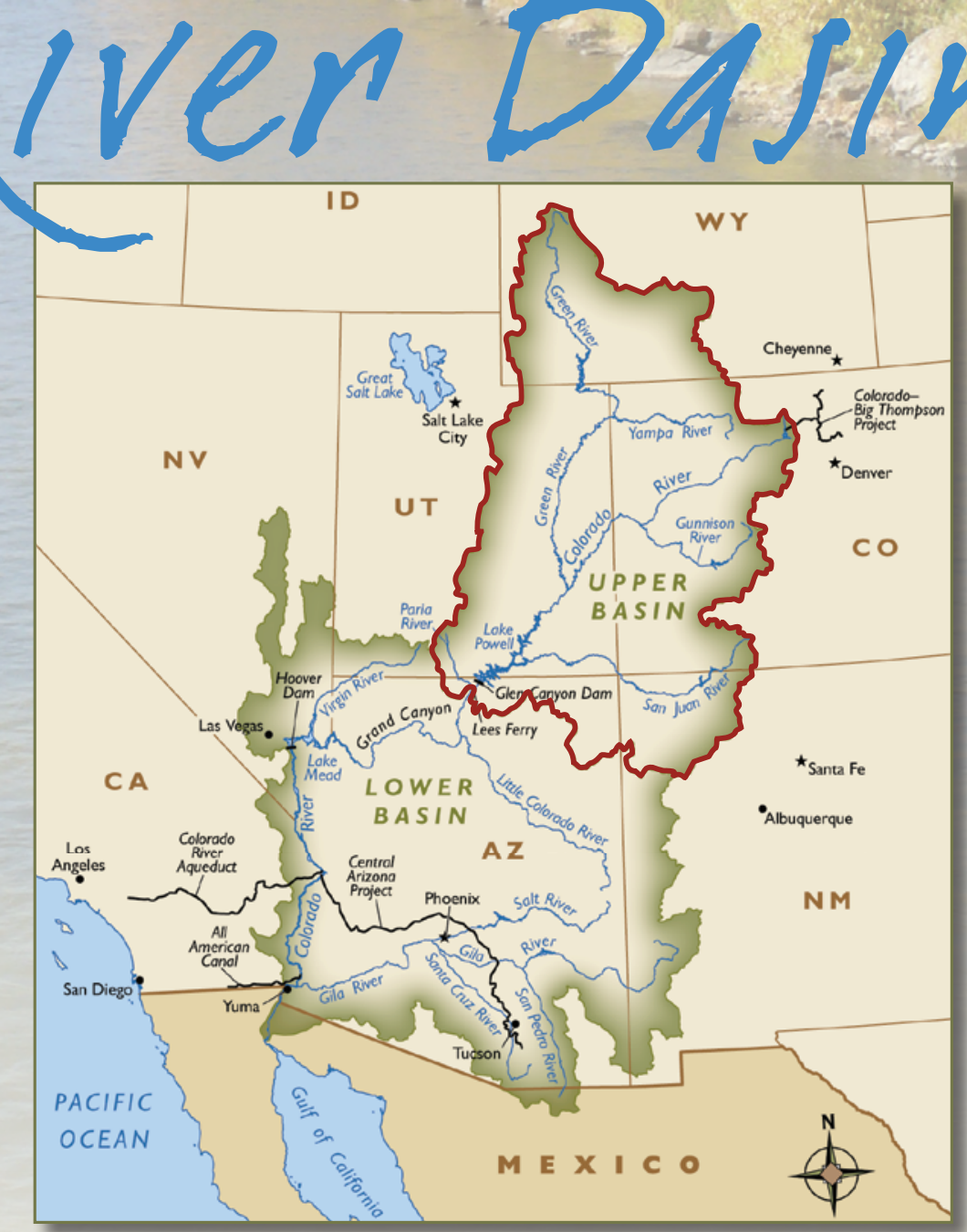

Figure 1. The Colorado River Basin with the Upper Basin outlined in red.

The U.S. Geological Survey (USGS) and numerous partners have ongoing research activities assessing the magnitude and effects of numerous climatic and human-induced changes affecting water availability and quality in the Colorado River Basin. This fact sheet summarizes selected major research efforts (both USGS and others) to evaluate the effects of climate and landscape change on water availability and water quality in the UCRB and describes some of the science needed to support future management decisions. 


\section{Climate Models Forecast Future Water Supply}

Current climate models predict that by 2100 , reductions in precipitation in the Southwestern United States, coupled with rises in temperatures as much as $5^{\circ} \mathrm{F}$, and associated increases in evapotranspiration could result in changes in water runoff in the Colorado River Basin of up to 20 percent (table 1) (Milly and others, 2005; Christensen and others, 2007; Seager and others, 2007). Models predict that by 2070 the Colorado River Compact and the U.S. agreements with Mexico will be met only 60 percent of the time (McCabe and Wolock, 2007; National Research Council, 2007). By 2050, increasing temperatures alone are expected to increase evaporation such that average soil moisture conditions in the Southwest may be lower than the conditions experienced during any of the most severe droughts of this century, including the 1930s Dust Bowl and the droughts of 1953-1956 or 1999-2004 (fig. 2). Increasing temperatures and reduced rainfall may also result in changes in vegetation cover. This, combined with other human disturbances related to land use and resource management, can affect the timing of snowmelt already altered by warming and may contribute to reduced total and late season water supplies in a substantial part of the American West. Related changes in water quantity and quality can create multiple natural-resource management and policy issues, affecting reservoir operations and water delivery for agriculture, communities, energy production, recreation, and wildlife.

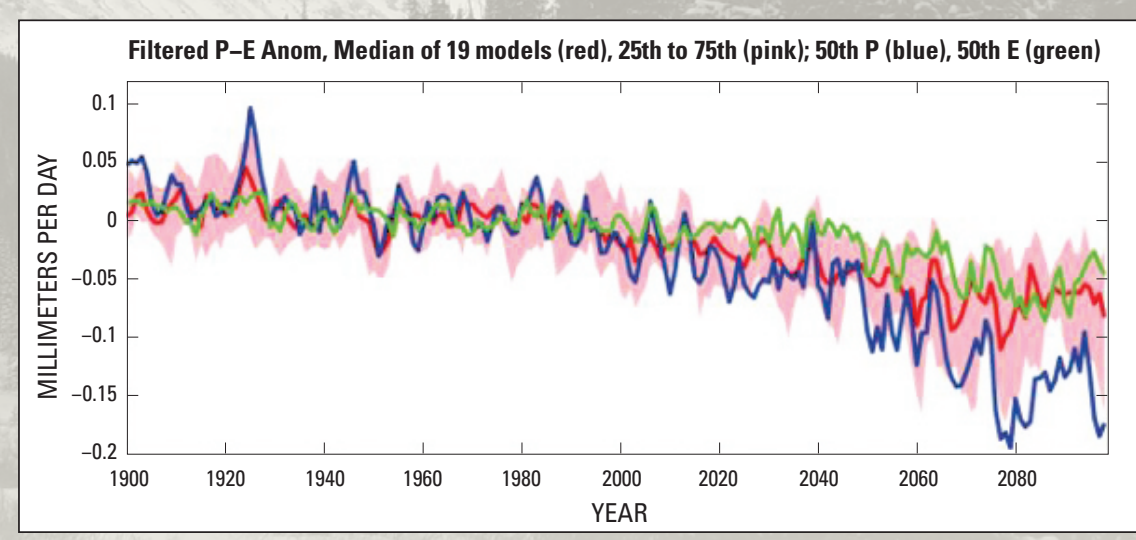

Figure 2. Modeled changes in annual mean precipitation (P) minus evaporation ( $E$ ) for the Southwestern United States, averaged over 19 models. Median values are in red and the 25th and 75th percentiles (pink shading) of the P-E distribution among the 19 models are shown, as are the ensemble medians of $P$ (blue line) and $E$ (green line) for $1900-2100$.

Background photograph by Dennis Smits, U.S. Geological Survey.

\section{Projected Future Flows in the Upper Colorado River Basin}

Recent models have indicated that climate change could reduce Colorado River Basin flow anywhere from 5 to 45 percent by 2050 (see table below). Given this wide range, an effort by scientists from the Bureau of Reclamation, the National Oceanic and Atmospheric Administration, USGS, and several universities to reconcile these diverse projections has shown:

1. Eighty-five percent of the runoff entering the Colorado River originates from the 15 percent of the basin at the highest elevations;

2. Models generating the largest reductions were not accurate; and

3. The most accurate models show the range of likely flows by 2050 are 5 to 20 percent less than current flows (Ray and others, 2009).

Table 1 and figure 2 illustrate how assumptions and analysis design affect future projections and how uncertainty of climate and runoff projections can be constrained. These results have been presented to Colorado River water managers, and future workshops are planned. For further information, contact Bradley Udall at bradley.udall@colorado.edu.

Table 1. Projected changes in Colorado River Basin runoff or streamflow in the mid-21st century. (Adapted from Ray and others, 2009.)

\begin{tabular}{|c|c|c|c|c|c|c|c|}
\hline Study & $\begin{array}{l}\text { Global } \\
\text { circulation models } \\
\text { (runs) }\end{array}$ & $\begin{array}{l}\text { Spatial } \\
\text { scale }\end{array}$ & Temperature & Precipitation & Year & Runoff (flow) & $\begin{array}{c}\text { Risk } \\
\text { estimate }\end{array}$ \\
\hline Christensen and others (2004) & $1(3)$ & $\begin{array}{l}\text { VIC model grid } \\
\qquad(\sim 8 \mathrm{mi})\end{array}$ & $+3.1^{\circ} \mathrm{F}$ & $-6 \%$ & $2040-69$ & $-18 \%$ & Yes \\
\hline Milly (2005) replotted by P.C.D. Milly & $\begin{array}{c}12(24) \\
(\sim 100-300 \mathrm{mi})\end{array}$ & CGM grids & - & & $2041-60$ & $\begin{array}{c}-10 \% \text { to }-20 \% \\
96 \% \text { model agreement }\end{array}$ & No \\
\hline Hoerling and Eischeid (2007) & $18(42)$ & $\begin{array}{l}\text { NCDC Climate } \\
\text { Division }\end{array}$ & $+5.0^{\circ} \mathrm{F}$ & $\sim 0 \%$ & $2035-60$ & $-45 \%$ & No \\
\hline Christensen and Lettenmaier (2007) & $11(22)$ & $\begin{array}{l}\text { VIC model grid } \\
\qquad(\sim 8 \mathrm{mi})\end{array}$ & $\begin{array}{c}+4.5^{\circ} \mathrm{F} \\
(+1.8 \text { to }+5.0)\end{array}$ & $\begin{array}{c}-1 \% \\
(-21 \% \text { to }+13 \%)\end{array}$ & $2040-69$ & $\begin{array}{c}-6 \% \\
(-40 \% \text { to }+18 \%)\end{array}$ & Yes \\
\hline Seager and others (2007)* & $19(49)$ & $\begin{array}{l}\text { CGM grids } \\
(\sim 100-300 \mathrm{mi})\end{array}$ & - & - & 2050 & $\begin{array}{c}-16 \% \\
(-8 \% \text { to }-25 \%)\end{array}$ & No \\
\hline McCabe and Wolock (2007) & - & $\begin{array}{l}\text { USGS HUC } 8 \text { units } \\
\qquad(\sim 25-65 \mathrm{mi})\end{array}$ & Assumed $+3.6^{\circ} \mathrm{F}$ & $0 \%$ & - & $-17 \%$ & Yes \\
\hline Barnett and Pierce (2008)* & - & - & - & - & 2057 & $\begin{array}{c}\text { Assumed } \\
-10 \% \text { to }-30 \%\end{array}$ & Yes \\
\hline
\end{tabular}

*Two studies are not specifically for the Upper Colorado River Basin. Seager and others (2007) is for a larger area that only partially overlaps the Upper Basin. Barnett and Pierce (2008) assume Lees Ferry streamflow changes to drive their water balance of reservoir storage. 


\section{The Reconstructed Paleoclimatic Record-The Past IIluminates the Future}

Paleoclimatic records show that the last 100 years have been unusually wet in the Upper Colorado River Basin. Reconstructions of past climatic conditions and associated Colorado River flows based on tree-ring records indicate the early 20th century was wetter than any time period back to A.D. 800 , and that period was wetter than most of the previous 10,000 years (fig. 3) (R.S. Thompson, oral commun., 2010). Droughts of greater intensity than any in the historical record occurred in the UCRB in the 11th, 14th, 15th, and 16th centuries and lasted as long as 24 years. In comparison, the longest 20th century drought lasted 14 years, and all droughts were less intense than those in previous centuries. There are other indicators that the past century has been far wetter than previous periods. Alpine lake levels in the Colorado mountains have been higher in the past millennium than any previous time in the past 5,000 to 12,000 years (Woodhouse and others, 2010). Paleobotanical evidence shows upper tree-line elevations ca. 9,000 to 5,000 years ago were at least 80 meters higher than those of today. Many climate models indicate warmer and drier future conditions in this region. Thus, if the past is a guide, then sustained periods of drought may return to the Upper Colorado River Basin. The warmer and drier future predicted by regional climate models is likely to exacerbate the drought conditions implied by the paleoclimate reconstructions creating conditions not yet experienced in recorded history. For further information, contact Bob Thompson at rthompson@usgs.gov.

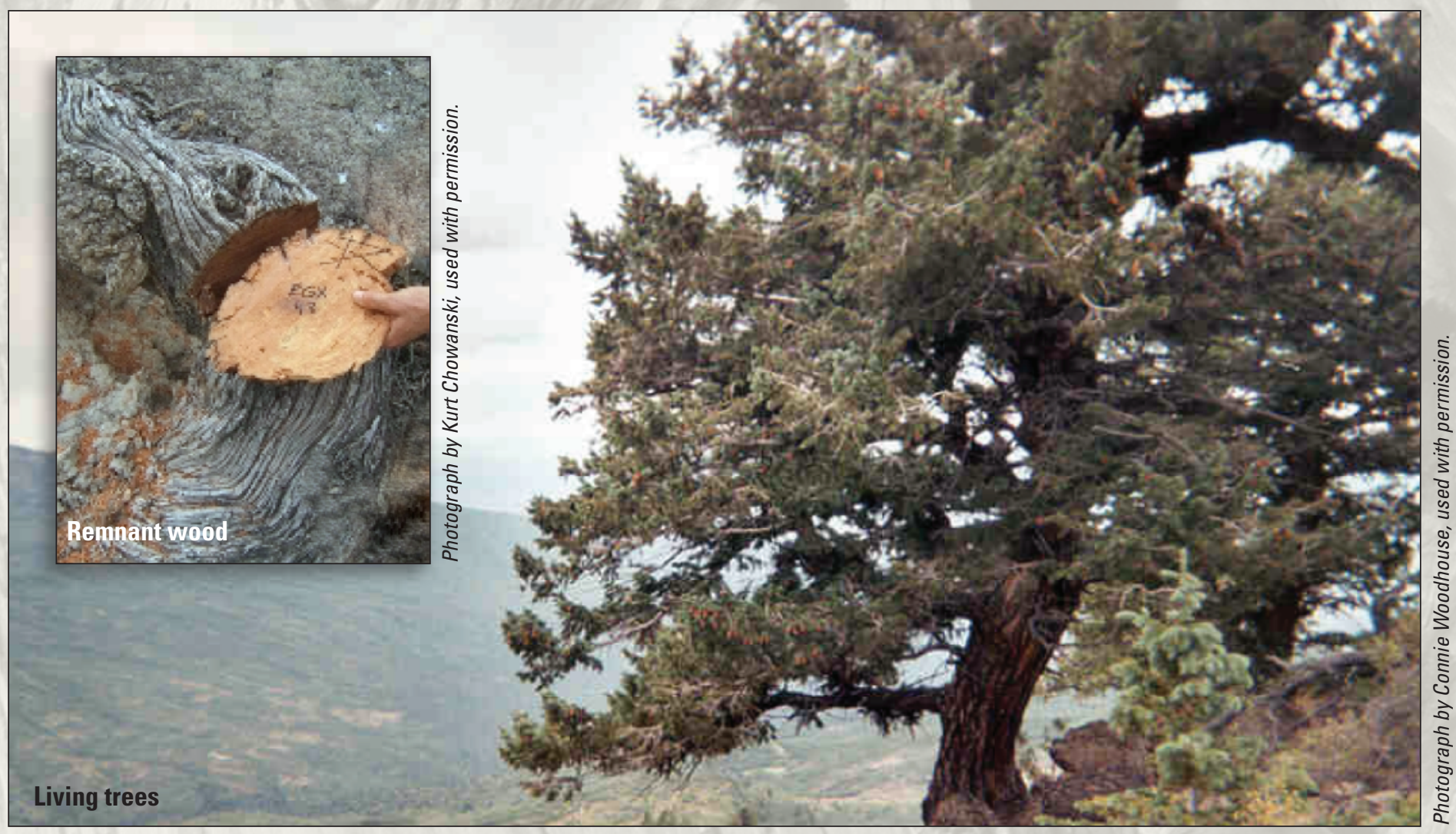




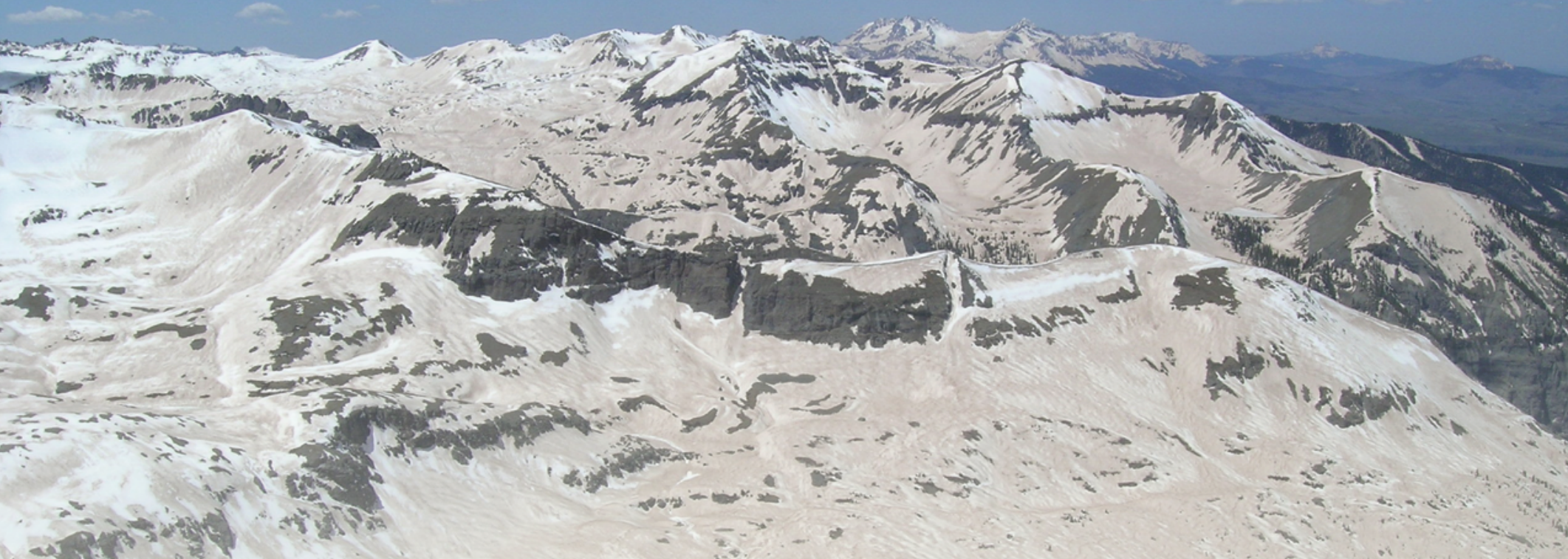

\section{Changes In the Timing of Snowmelt and Streamflow In the Upper Colorado River Basin}

More than 80 percent of the runoff from the UCRB comes from the melting of high-elevation snow. The mountain snowpack serves as a large natural reservoir, releasing water for humans and wildlife throughout the West during the spring and summer. Since the late 1970s, the onset of snowmelt in this region has shifted 2 to 3 weeks earlier coincident with increasing spring temperatures and declining snowfall (Clow, 2010). Climate projections indicate that snowmelt timing will continue to advance in response to additional warming (Rauscher and others, 2008). Windblown dust loading on the mountain snowpack may exacerbate the problem (see photographs and following section). The observed trends in snowmelt timing have resulted in a similar shift in streamflow timing; these changes may require changes in reservoir management and water usage by cities and farms and may have important implications for fish and other aquatic biota that depend on maintenance of minimum streamflows during the fall and winter low-flow period. For further information, contact Dave Clow atdclow@usgs.gov or Tom Painter at thomas.painter@jpl.nasa.gov.

\section{Airborne Dust_Land-Use Management and Effects on Water Supply}

Wind-driven dust production is increased by drought, disturbance of the soil surface, the invasion of exotic annual grasses, and fire. A synergistic effect is created when surface disturbance occurs on invaded landscapes during drought years, and large amounts of soil can be lost from an area as a result (Belnap and others, 2009). Soil-disturbing activities - energy exploration and development, grazing, and recreation - in the UCRB reduce plant and soil-crust cover that provides soil-surface protection. Increasing temperatures and decreasing precipitation also slow the recovery of soil and vegetation from land-use disturbance, further increasing the frequency and magnitude of wind erosion.

Large dust storms have both local and regional effects on water resources. Windblown material is deposited in ephemeral washes, and this additional sediment degrades water quality when water flows. In the UCRB, these sediments are commonly heavily laden with salts and heavy metals (Bentley and others, 1978) such as selenium, degrading water quality and affecting wildlife downstream. Most importantly, much of the dust produced from low-elevation land can be deposited on the snowpack of nearby mountains (Painter and others, 2007). During spring warming, the dark-colored dust absorbs heat, which increases the rate at which the underlying snowpack melts. Models show up to 7 percent of the annual input to the Colorado River results from early snowmelt (Painter and others, 2010). Earlier than usual runoff is problematic for water managers and commonly reduces our ability to store water. Early snowmelt also leaves soils exposed longer to solar radiation, increasing evaporation from plants and soils and the potential for dust generation. Both wind- and water-borne sediment is likely to reduce the quality and quantity of water in the Colorado River watershed. Identifying the type, size, and source of dust allows land managers to better locate the landscapes that are susceptible to generating dust and adjust the timing, intensity, and location of soil-disturbing activities in these areas during seasons when the potential for dust production is high. For further information, contact Jayne Belnap at jayne_belnap@usgs.gov or Tom Painter at thomas.painter@jpl.nasa.gov.

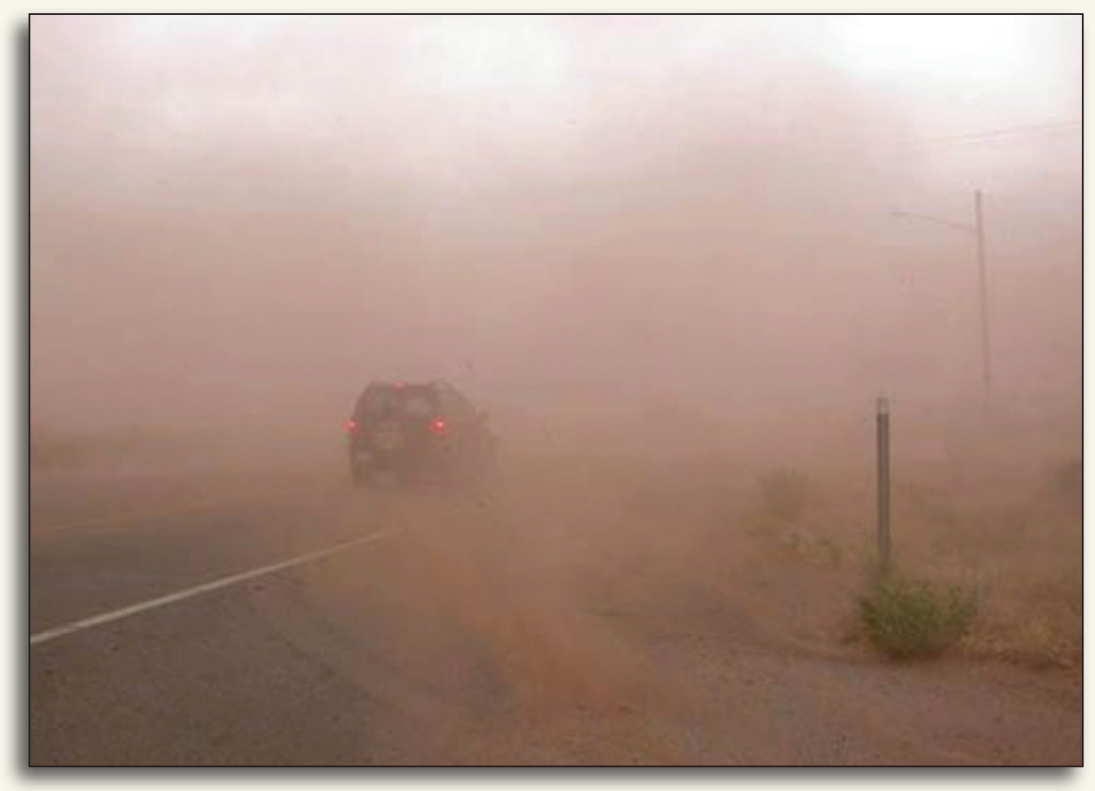


In addition to climate change, other factors may affect local and regional water supplies. At higher elevations, trees are succumbing to beetle kill and drought, with large areas of dead trees now present in Colorado, New Mexico, Arizona, and Utah. Although the mountain pine beetle (Dendroctonus ponderosae) is a native insect, several factors have contributed to its current epidemic population outbreak: increasing air temperatures and recent drought (possibly related to climatic change) and the presence of contiguous stands of mature, dense forest. Trees are now dead and dying throughout over 3 million acres of Colorado forests. This mortality could significantly decrease water quality and likely will affect snowmelt rates and runoff timing. USGS scientists are collaborating with several local and Federal partners on interdisciplinary research to characterize effects of this large-scale forest mortality on ecosystem structure and function, potential fire hazard, and water resources in this region. The quantity and timing of water supply is being monitored to detect changes related to forest die-off. Changes in water quality have already been detected. Although nitrate concentrations in streams flowing into and out of key drinking-water reservoirs in the headwaters of the Colorado River have remained stable or even declined, total phosphorus concentrations have increased in some streams by 30 to 60 percent since the beetle infestation began (Dave Clow, U.S. Geological Survey, oral commun., 2010). This may contribute to algal blooms that can cause anoxia and fishkills in the reservoirs. Results from these studies will help water-resource managers and water suppliers to understand, plan for, and adapt to changes in the quality of water available for consumptive use in the Upper Colorado River Basin and adjacent watersheds. For further information, contact Dave Clow at dclow@usgs.gov or Jenny Briggs at jsbriggs@usgs.gov.

\section{Fish Futures and Changing Riparian Habitat in the Colorado River Basin}

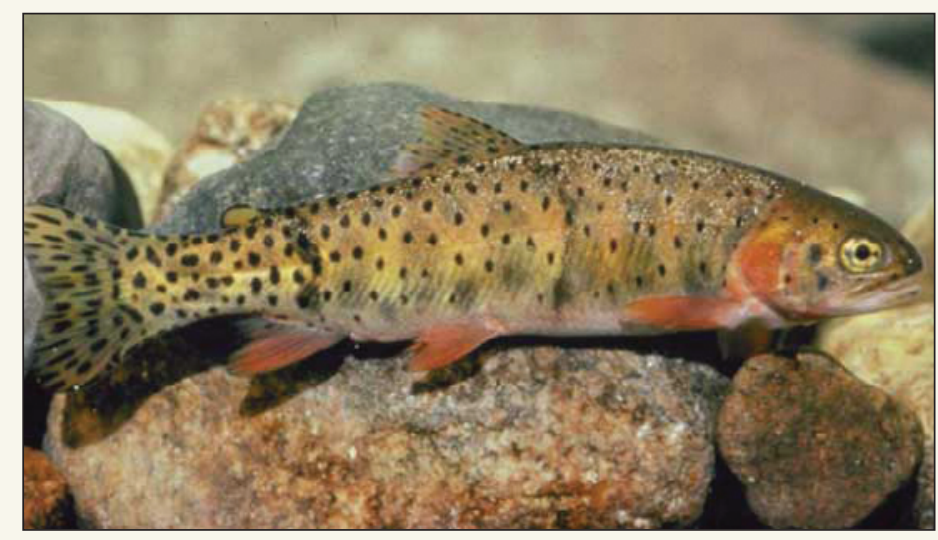

Colorado River Cutthroat Trout

Native fishes in the Colorado River and its tributaries evolved in a dynamic environment, with extreme swings in water flow and sediment loads. However, large dams have altered the timing, amount, and temperature of river flows. These changes, when combined with the introduction of nonnative reservoir and river fishes, have imperiled native fishes. Future projections for the Colorado River include reduced flows, warmer water, and greater human demands for this water. Although the effects of changing water temperatures on the interactions between native and nonnative fishes is not known, it is known that declining water availability will make the restoration of endangered fish habitat extremely challenging.

Riparian areas in the Colorado River Basin are important transitions between the arid uplands and water bodies. Riparian areas provide diverse habitat for a large variety of plant and animal species, important linkage corridors for amphibians, birds, and mammals, and breeding areas for many species. Species like cottonwood depend on high spring flows for germination, and these conditions may not occur in the future, threatening these large gallery forests and the species associated with them. As river flows decrease and human demands increase, there may be an increasing need for surface-water and groundwater withdrawal. These withdrawals may dry up streams and springs, thus eliminating many riparian habitats and endangering the living things that depend on them. For further information, contact Jeffrey Kershner at jeffrey_kershner@usgs.gov. 


\section{Science in Support of Management Decisions}

Science is critical for making informed natural resource management decisions. The U.S. Geological Survey and Federal and nonFederal partners are exploring ways to mitigate and adapt to future climate and landscape changes. Still, there are many critical research and monitoring efforts needed to enhance this effort, including the following examples:

- Maintain and augment current monitoring networks, such as streamflow, water quality, snowmelt, groundwater, springs, vegetation, air quality, aquatic ecosystems, and climate, to document how resources are changing. Consider establishing instrumented watersheds to better understand how hydrology, climate, land use, and vegetation interact to influence water quantity and quality.

- Document climatic and land-use histories to provide context in which to understand current trends.

- Monitor and measure dust at chronic and acute dust sources. Expand mapping of vulnerable soils and suggest ways to reduce dust production.

- Develop better understanding of groundwater recharge and how to assess the effects of water withdrawals.

- Develop forecasting abilities for climate and water supplies across different temporal and spatial scales to evaluate the potential consequences of alternative management scenarios.

- Develop integrated tools for evaluating watershed-scale ecosystem health.

- Document the effects of altered hydrologic cycles on aquatic and riparian resources, as stresses on these landscape components increase in the future.

- Enhance communication between scientists and managers/policymakers.

\section{References}

Andreadis, K.M., and Lettenmaier, D.P., 2006, Trends in 20th century drought over the continental United States: Geophysical Research Letters, v. 33, p. L10403, doi:10.1029/2006GL025711.

Barnett, T.P., and Pierce D.W., 2008, When will Lake Mead go dry?: Water Resources Research, 44, W03201, doi:10.1029/2007WR006704.

Belnap, Jayne, Reynolds, R.L., and others, 2009, Sediment losses and gains across a gradient of livestock grazing and plant invasion in a cool, semi-arid grassland, Colorado Plateau, USA: Aeolian Research v. 1, p. 27-43.

Bentley, R.G., Jr., Eggleston, K.O., Price, D., Frandsen, E.R., and Dickerman, A.R., 1978, The effects of surface disturbance (primarily livestock use) on the salinity of public lands in the Upper Colorado River Basin-1977 Status Report: Denver, Colorado, U.S. Department of the Interior, Bureau of Land Management, Denver Service Center, Division of Standards and Technology, Watershed Staff.

Christensen, J.H., Hewitson, B., Busuioc, A., Chen, A., Gao, X., Held, I., Jones, R., Kolli, R.K., Kwon, W.T., Laprise, R., Magaña Rueda, V., Mearns, L., Menéndez, C.G., Räisänen, J., Rinke, A., Sarr, A., and Whetton, P., 2007, Regional climate projections, in Solomon, S., Qin, D., Manning, M., Chen, Z., Marquis, M., Averyt, K.B., Tignor, M., and Miller, H.L., eds., Climate change 2007-The physical science basis: Contribution of Working Group I to the Fourth Assessment Report of the Intergovernmental Panel on Climate Change, Cambridge, Cambridge University Press, p. 848-940.

Christensen N.S., and Lettenmeier, D.P., 2007, A multimodel ensemble approach to assessment of climate change impacts on the hydrology and water resources of the Colorado River Basin: Hydrology and EarthSystem Sciences, 11, p. 1417-1434.

Clow, D.W., 2010, Changes in the timing of snowmelt and streamflow in Colorado-A response to recent warming: Journal of Climate, v. 23, no. 9, p. 2293-2306.

Hoerling, M. and Eischeid, J., 2007, Past peak water in the Southwest: Southwest Hydrology, 35, p. 18-19, 35.

McCabe, G.J., and Wolock, D.M., 2007, Warming may create substantial water supply shortages in the Colorado River basin: Geophysical Research Letters, v. 34, p. L22708, doi:10.1029/2007GL031764.

Milly, P.C.D., Dunne, K.A., and Vecchia, A.V., 2005, Global pattern of trends in streamflow and water availability in a changing climate: Nature, v. 438, p. 347-350, doi:10.1038/nature04312.
National Research Council, Committee on the Scientific Bases of Colorado River Basin Water Management, 2007, Colorado River Basin Water Management-Evaluating and adjusting to hydroclimatic variability: Washington, D.C., National Academies Press, 242 p.

Painter, T.H., Barrett, A.P., Landry, C.C., Neff, J.C., Cassidy, M.P., Lawrence, C.R., McBride, K.E., and Farmer, G.L., 2007, Impact of disturbed desert soils on duration of mountain snow cover: Geophysical Research Letters, v. 34, no. L12502, doi:10.1029/2007GL030284.

Painter, T.H., Deems, J.S., Belnap, J., Hamlet, A.F., Landry, C.C., and Udall, B.H., 2010, Response of Colorado River runoff to dust radiative forcing in snow: Proceedings of the National Academy of Sciences (PNAS), accessed Oct. 19, 2010, at http://www.pnas.org/content/107/40/17125.

Pulwarty, R., Jacobs, K., and Dole, R., 2005, The hardest working riverDrought and critical water problems on the Colorado, in Wilhite, D., ed., Drought and water crises-Science, technology and management: New York, Taylor and Francis Press, p. 249-285.

Rauscher, S.A., Pal, J.S., Diffenbaugh, N.S., and Benedetti, M.M., 2008, Future changes in snowmelt-driven runoff timing over the western US: Geophysical Research Letters, v. 35, doi:10.1029/2008GL034424.

Ray, A.J., Barsugli, J.J., Averyt, K.B., Wolter, K., Hoerling, M., Doesken, N., Udall, B., and Webb, R.S., 2009, Climate change in Colorado-A synthesis to support water resources management and adaptation: Colorado Water Conservation Board, State of Colorado, at http://cwcb.state.co.us/ public-information/publications/Documents/ReportsStudies/ ClimateChangeReportFull.pdf.

Seager, R., Ting, M., Held, I., Kushnir, Y., Lu, J., Vecchi, G., Huang, H., Harnik, N., Leetmaa, A., Lau, N., Li, C., Velez, J., and Naik, N., 2007, Model predictions of an imminent transition to a more arid climate in Southwestern North America: Science, v. 316, p. 1181-1184.

Woodhouse, C.A., Meko, D.M., MacDonald, G.M., Stahle, D.W., and Cook, E.R., 2010, A 1,200-year perspective of 21 st century drought in southwestern North America: Proceedings of hte National Academy of Sciences, v. 107, no. 50 , p. 21283-21288.

For further information contact:

Jayne Belnap

U.S. Geological Survey

Moab, Utah

jayne_belnap@usgs.gov

Donald H. Campbell

U.S. Geological Survey

Denver, Colorado

dhcampbe@usgs.gov 